\title{
Haloanaerobium alcaliphilum sp. nov., an Anaerobic Moderate Halophile from the Sediments of Great Salt Lake, Utah
}

\author{
CHIA-RONG TSAI, ${ }^{1}$ JEAN-LOUIS GARCIA, ${ }^{1,2 *}$ BHARAT K. C. PATEL, ${ }^{2,3}$ \\ JEAN-LUC CAYOL, ${ }^{2}$ LARRY BARESI, ${ }^{1}$ AND ROBERT A. MAH ${ }^{1}$ \\ Department of Environmental Health Sciences, School of Public Health, University of California, Los Angeles, \\ California 90024-1772 ${ }^{1}$; Laboratoire de Microbiologie ORSTOM, Universite de Provence, Marseille, France ${ }^{2}$; \\ and Faculty of Science and Technology, Griffith University, Nathan 4111, Brisbane, Australia ${ }^{3}$
}

\begin{abstract}
A strictly anaerobic, moderately halophilic, gram-negative, rod-shaped bacterium was isolated from Great Salt Lake, Utah, sediments and designated GSLS ${ }^{\mathrm{T}}\left(\mathrm{T}=\right.$ type strain). Strain GSLS ${ }^{\mathrm{T}}$ grew optimally at pH 6.7 to 7.0 but had a very broad $\mathrm{pH}$ range for growth (pH 5.8 to 10.0). The optimum temperature for growth was $37^{\circ} \mathrm{C}$, and no growth occurred at 15 or $55^{\circ} \mathrm{C}$. The optimum salt concentration for growth was $10 \%$. Strain GSLS $^{\mathrm{T}}$ required yeast extract and Trypticase peptone to ferment carbohydrates, pyruvate, and glycine betaine. Strain GSLS ${ }^{\mathrm{T}}$ was resistant to penicillin, D-cycloserine, tetracycline, and streptomycin. The $\mathbf{G}+\mathrm{C}$ content of this isolate was $31 \mathrm{~mol} \%$. The fermentation products from glucose utilization were acetate, butyrate, lactate, $\mathrm{CO}_{2}$, and $\mathrm{H}_{2}$, and in addition strain GSLS ${ }^{\mathrm{T}}$ fermented glycine betaine to acetate and trimethylamine. All of these traits distinguish this organism from all previously described halophilic anaerobes. The 16S rRNA gene sequence of strain GSLS ${ }^{\mathrm{T}}$ was found to be similar to, but also significantly different from, the 16S rRNA sequences of Haloanaerobium salsugo and Haloanaerobium praevalens. Therefore, strain GSLS ${ }^{\mathrm{T}}\left(=\mathrm{DSM} \mathrm{8275}^{\mathrm{T}}\right.$ ) is described as a new species, Haloanaerobium alcaliphilum.
\end{abstract}

There have been few studies of halophilic anaerobes and the ability of these organisms to break down organic matter in saline environments. The ability to grow in the presence of various concentrations of salt distinguishes the following three groups of halophiles (11): (i) the haloduric halophiles (optimum salt concentration, 2 to $5 \%$ ), (ii) the moderate halophiles (optimum salt concentration, 5 to $20 \%$ ), and (iii) the extreme halophiles (optimum salt concentration, 20 to $30 \%$ ). Members of all three groups have been reported to inhabit anaerobic saline habitats (34).

Eight halophilic, carbohydrate-fermenting, anaerobic genera containing 13 species and belonging to the domain Bacteria have been described previously (18). Seven of these species have been classified as members of the family Haloanaerobiaceae on the basis of their 16S rRNA oligonucleotide sequences $(20,21)$. All isolates of these species ferment carbohydrates, and some use starch (20), pectin (36), glycogen (20), chitin (13), or cellulose (31). Most strains are moderately halophilic as their optimum salt concentrations for growth are 3 to $15 \%$.

Fermentation patterns clearly distinguish the eight genera that have been described. Species belonging to the genus Halobacteroides $(23,30,37,38)$, Haloanaerobium salsugo (1), and Halothermothrix orenii (3) produce acetate, ethanol, $\mathrm{H}_{2}$, and $\mathrm{CO}_{2}$ from glucose, whereas Haloanaerobium praevalens produces acetate, propionate, butyrate, $\mathrm{H}_{2}$, and $\mathrm{CO}_{2}(36)$. Isobutyrate production has been observed only during growth of Haloanaerobacter chitinovorans (13) and Sporohalobacter lortetii (22). The spore-forming organism Sporohalobacter marismortui oxidizes carbohydrates to a mixture of ethanol and volatile fatty acids, including formic acid (20). Halocella cellulolytica ferments glucose to acetate, ethanol, lactate, $\mathrm{H}_{2}$, and $\mathrm{CO}_{2}$ (31). Haloincola saccharolytica $(2,40)$ and Acetohalobium

${ }^{*}$ Corresponding author. Mailing address: Laboratoire de Microbiologie ORSTOM, Université de Provence, Case 87, 3 Place Victor Hugo, 13331 Marseille cedex 3, France. Phone: (33) 91.10.64.78. Fax: (33) 91.10.64.81. Electronic mail address: rogerpa@loma.orstom.fr. arabaticum (39) exhibit a homoacetogenic pathway of glucose metabolism.

We isolated a moderately halophilic, fermentative strain from sediments collected from underneath a salt layer in Great Salt Lake, Utah. In this paper we describe this strain as a new species of the genus Haloanaerobium, Haloanaerobium alcaliphilum.

\section{MATERIALS AND METHODS}

Origin of samples. Samples were collected from the north arm of the Great Salt Lake in Utah. The sampling site was located $3 \mathrm{~km}$ offshore at the midpoint of a line drawn between the Little Valley Shelter and the Cub Island Shelter. Grab samples were obtained from brine at a depth of $7 \mathrm{~m}$ after the salt crust was broken with an orange peel sampler. The samples were collected under anaerobic conditions in serum bottles, transported to a laboratory at the ambient temperature, and stored at $4^{\circ} \mathrm{C}$ until they were used.

Origin of strain SLP. Methanohalophilus mahii SLP (= OCM 68) was obtained from the Oregon Collection of Methanogens, Beaverton.

Isolation and culture techniques. The modified anaerobic technique of Hungate $(8,15)$ was used throughout this study. The basic medium used to produce axenic cultures contained (per liter) $17 \mathrm{~g}$ of $\mathrm{MgSO}_{4} \cdot 7 \mathrm{H}_{2} \mathrm{O}, 100 \mathrm{~g}$ of $\mathrm{NaCl}, 50 \mathrm{ml}$ of mineral solution A ( $6 \mathrm{~g}$ of $\mathrm{K}_{2} \mathrm{HPO}_{4}$ per liter of distilled water), $50 \mathrm{ml}$ of mineral solution $\mathrm{B}$ [which contained (per liter of distilled water) $6 \mathrm{~g}$ of $\mathrm{KH}_{2} \mathrm{PO}_{4}$, $6 \mathrm{~g}$ of $\left(\mathrm{NH}_{4}\right)_{2} \mathrm{SO}_{4}, 12 \mathrm{~g}$ of NaCl, $2.6 \mathrm{~g}$ of $\mathrm{MgSO}_{4} \cdot 7 \mathrm{H}_{2} \mathrm{O}, 25 \mathrm{~g}$ of $\mathrm{NH}_{4} \mathrm{Cl}, 0.28 \mathrm{~g}$ of $\mathrm{CaCl}_{2} \cdot 2 \mathrm{H}_{2} \mathrm{O}$, and $0.28 \mathrm{~g}$ of $\mathrm{K}_{2} \mathrm{HPO}_{4}$ ], $10 \mathrm{ml}$ of a trace mineral solution [which contained (per liter of distilled water) $0.5 \mathrm{~g}$ of $\mathrm{MnSO}_{4} \cdot \mathrm{H}_{2} \mathrm{O}, 0.1 \mathrm{~g}$ of $\mathrm{FeSO}_{4} \cdot 7 \mathrm{H}_{2} \mathrm{O}, 0.1 \mathrm{~g}$ of $\mathrm{CoCl}_{2} \cdot 6 \mathrm{H}_{2} \mathrm{O}, 0.1 \mathrm{~g}$ of $\mathrm{ZnSO}_{4} \cdot 7 \mathrm{H}_{2} \mathrm{O}, 0.01 \mathrm{~g}$ of $\mathrm{CuSO}_{4} \cdot 5 \mathrm{H}_{2} \mathrm{O}, 0.01 \mathrm{~g}$ of $\mathrm{AlK}\left(\mathrm{SO}_{4}\right)_{2} \cdot 12 \mathrm{H}_{2} \mathrm{O}, 0.01 \mathrm{~g}$ of $\mathrm{H}_{3} \mathrm{BO}_{3}, 0.01 \mathrm{~g}$ of $\mathrm{NaMoO}_{4} \cdot 2 \mathrm{H}_{2} \mathrm{O}, 0.05 \mathrm{~g}$ of $\mathrm{NiCl}_{2} \cdot 6 \mathrm{H}_{2} \mathrm{O}, 0.263 \mathrm{~g}$ of $\mathrm{NaSeO}_{3} \cdot 5 \mathrm{H}_{2} \mathrm{O}$, and $1.5 \mathrm{~g}$ of nitrilotriacetic acid; the components were dissolved with $\mathrm{KOH}$ and adjusted to $\mathrm{pH} 6.5$, and the final $\mathrm{pH}$ was 7.0$], 10 \mathrm{ml}$ of a vitamin solution (which contained [per liter of distilled water] $2 \mathrm{mg}$ of biotin, $2 \mathrm{mg}$ of folic acid, $10 \mathrm{mg}$ of pyridoxine hydrochloride, $5 \mathrm{mg}$ of thiamine hydrochloride, $5 \mathrm{mg}$ of riboflavin, $5 \mathrm{mg}$ of nicotinic acid, $5 \mathrm{mg}$ of DL-calcium pantothenate, $0.1 \mathrm{mg}$ of vitamin $\mathrm{B}_{12}, 5 \mathrm{mg}$ of $p$-aminobenzoic acid, and $5 \mathrm{mg}$ of lipoic acid), and $1 \mathrm{ml}$ of $0.1 \%$ resazurin. After boiling under a stream of oxygen free $\mathrm{N}_{2}-\mathrm{CO}_{2}(70: 30), 4.1 \mathrm{~g}$ of $\mathrm{NaHCO}_{3}$ and 0.5 $\mathrm{g}$ of $\mathrm{L}$-cysteine were added. The following components were added to the mineral medium after stock solutions were autoclaved at $120^{\circ} \mathrm{C}$ for $20 \mathrm{~min}$ (final concentrations): yeast extract (Difco Laboratories, Detroit, Mich.) (10 g/liter), Trypticase (Becton Dickinson, Cockeysville, Md.) (10 g/liter), $\mathrm{Na}_{2} \mathrm{~S} \cdot 9 \mathrm{H}_{2} \mathrm{O}(0.25$ $\mathrm{g} / \mathrm{liter}$ ). The medium was dispensed into Hungate tubes and flasks (17) under a stream of $\mathrm{N}_{2}-\mathrm{CO}_{2}(70: 30)$. To prepare solid media for plates and roll tubes, Bacto Agar (Difco) was added to the medium to a final concentration of $1.25 \%$.

Dilutions of each sediment sample were streaked directly onto plates in an 
anaerobic glove box (Coy Laboratory Products, Inc., Ann Arbor, Mich.), and the plates were incubated in an anaerobic jar for several days. Colonies were picked and serially diluted in liquid basic medium in 60-ml serum bottles (Wheaton Scientific Co., Milleville, N.J.) in an anaerobic hood. The cultures were incubated at $37^{\circ} \mathrm{C}$ without shaking until an increase in turbidity was detected. These cultures were subcultured into fresh medium (inoculum, 10\%). Positive cultures were transferred subsequently five more times every 3 days. Further purification was achieved by the roll tube method (8). Well-isolated colonies were picked by using a finely drawn Pasteur pipette and were introduced into liquid dilution medium prior to inoculation into roll tube media. After growth and colony formation, this process was repeated several times until an axenic culture was obtained. Culture purity was assessed by examining colony morphology (pure cultures contained uniform colonies) and by phase-contrast microscopy.

Physiological tests. The effect of salt on growth was determined in triplicate by inoculating 1-ml portions of a culture of strain $\operatorname{GSLS}^{\mathrm{T}}(\mathrm{T}=$ type strain) into anaerobic tubes that contained $9 \mathrm{ml}$ of the basic medium described above and $\mathrm{NaCl}$ at concentrations ranging from 0 to $30 \%(\mathrm{wt} / \mathrm{vol})$. The maximum growth rates of the resulting cultures were estimated during the early exponential phase. The effect of temperature was determined with medium that contained the optimum salt concentration. The effect of $\mathrm{pH}$ was determined by using the following four organic buffers: Walpole's acetate buffer (32), MES [2-( $N$-morpholino)ethanesulfonic acid], Bis-Tris propane [1,3-bis(tris(hydroxymethyl) methylamino)propane], and Sorensen's glycine buffer (32) at a final concentration of $50 \mathrm{mM}$. The $\mathrm{pH}$ values after sterilization ranged from $\mathrm{pH} 5.0$ to 11.0 .

Fermentation of carbon substrates (final concentration, $0.5 \%$ ) was investigated in triplicate by using the basic medium containing $1 \mathrm{~g}$ of yeast extract per liter and $1 \mathrm{~g}$ of Trypticase per liter. Each growth rate was compared with the growth rate in a control tube containing $1 \mathrm{~g}$ of yeast extract per liter and $1 \mathrm{~g}$ of Trypticase per liter but no carbohydrate. The criterion used for positive substrate utilization was a maximum growth rate of at least $0.2 \mathrm{~h}^{-1}$. The generation time was determined from changes in optical density when cells were grown on a medium containing $0.5 \%$ glucose under optimal conditions. Prototrophic growth was tested in glucose medium that lacked yeast extract and Trypticase.

The Gram reaction was determined with heat-fixed liquid cultures stained with Difco kit reagents. Antibiotic susceptibility was determined in liquid medium by using the following antibiotics at concentrations ranging from 100 to $1,000 \mu \mathrm{g} / \mathrm{ml}$ : D-cycloserine, penicillin G, streptomycin, and tetracycline. Whether oxygen could be used as an electron acceptor was determined on solid medium; whether fumarate $(10 \mathrm{mM})$ or nitrate $(10 \mathrm{mM})$ could be used as an electron acceptor was determined with glucose; and whether sulfate $(10 \mathrm{mM})$ could be used as an electron acceptor was determined by using lactate in liquid medium under $\mathrm{N}_{2}-\mathrm{CO}_{2}$. Growth on $\mathrm{H}_{2}-\mathrm{CO}_{2}$ (80:20) was examined in liquid medium in order to test for homoacetogenesis.

Growth on glycine betaine was tested by using a coculture of strain GSLS ${ }^{\mathrm{T}}$ and M. mahii, a halophilic, methylotrophic methanogen isolated from Great Salt Lake (25). These experiments were performed in serum bottles containing the basic medium supplemented with $1 \%$ glycine betaine, $0.1 \%$ yeast extract, $0.1 \%$ Trypticase, and $10 \% \mathrm{NaCl}$ and inoculated with $1.5 \mathrm{ml}$ of an exponentially growing culture of each organism. Methane evolution was monitored by gas chromatography as described below.

Analytical techniques. Growth rates were determined by measuring the optical densities of cultures at $560 \mathrm{~nm}$ with a Junior model 35 spectrophotometer (Perkin-Elmer, Oak Brook, Ill.). Volatile fatty acids and carboxylic acids from the fermentation of glucose and glycine betaine cocultures in the supernatants of the growth medium were analyzed by gas chromatography as described previously (5) and by high-performance liquid chromatography (HPLC) (Shimadzu Corp., Kyoto, Japan), using a reverse-phase $\mathrm{C}_{18}$ column $(4 \mathrm{~mm}$ by $30 \mathrm{~cm}$ Spherisorb $\mathrm{C}_{18}$; Interchim, Montluçon, France) and a UV spectrophotometric detector (model SPD6A; Shimadzu Corp.) set at $225 \mathrm{~nm}$. The mobile phase consisted of $20 \%$ acetonitrile in $0.01 \mathrm{~N}$ hydrochloric acid. $\mathrm{H}_{2} \mathrm{~S}$ contents were determined photometrically as previously described (4). The $\mathrm{H}_{2}, \mathrm{CO}_{2}$, and $\mathrm{CH}_{4}$ in the gas phase above the growth medium were analyzed by gas chromatography as described previously (5).

Electron microscopy. Electron micrographs were obtained by using a JEOL model JEM-1200 EX transmission electron microscope and negative staining with $1 \%(\mathrm{wt} / \mathrm{vol})$ sodium phosphotungstate.

DNA base composition. DNA was isolated by the technique of Pitcher et al. (28). The guanine-plus-cytosine $(\mathrm{G}+\mathrm{C})$ content of the DNA was determined at the DSM-Deutsche Sammlung von Mikroorganismen und Zellkulturen GmbH, Braunschweig, Germany, by using the methods described by Meshbah et al. (16) and Tamaoka and Komagata (33).

$16 S$ rRNA sequence studies. Semipurified DNA was extracted and used to amplify the 16S rRNA gene by the following protocol. Cultures $(2 \mathrm{ml})$ were centrifuged, and the pellets were resuspended in $50 \mu$ of lysis buffer $(50 \mathrm{mM}$ Tris- $\mathrm{HCl}$ [pH 7.2], $50 \mathrm{mM}$ EDTA, 3\% sodium dodecyl sulfate) and placed in microcentrifuge tubes. Each suspension was microwaved at $600 \mathrm{~W}$ for $30 \mathrm{~s}$ by using $15 \mathrm{~s}$ of heat on and $5 \mathrm{~s}$ of heat off four times while the lids were open. Then $350 \mu \mathrm{l}$ of lysis buffer was added to each tube, the lids were closed, the preparations were incubated at $80^{\circ} \mathrm{C}$ for $15 \mathrm{~min}$, and $400 \mu$ l of phenol-chloroform (1:1) was added to each suspension. Each preparation was centrifuged at $13,000 \times g$ for $15 \mathrm{~min}$, and then the top aqueous phase (approximately $200 \mu \mathrm{l}$ ) was removed; we were careful to avoid any material from the interface when we did this. Then

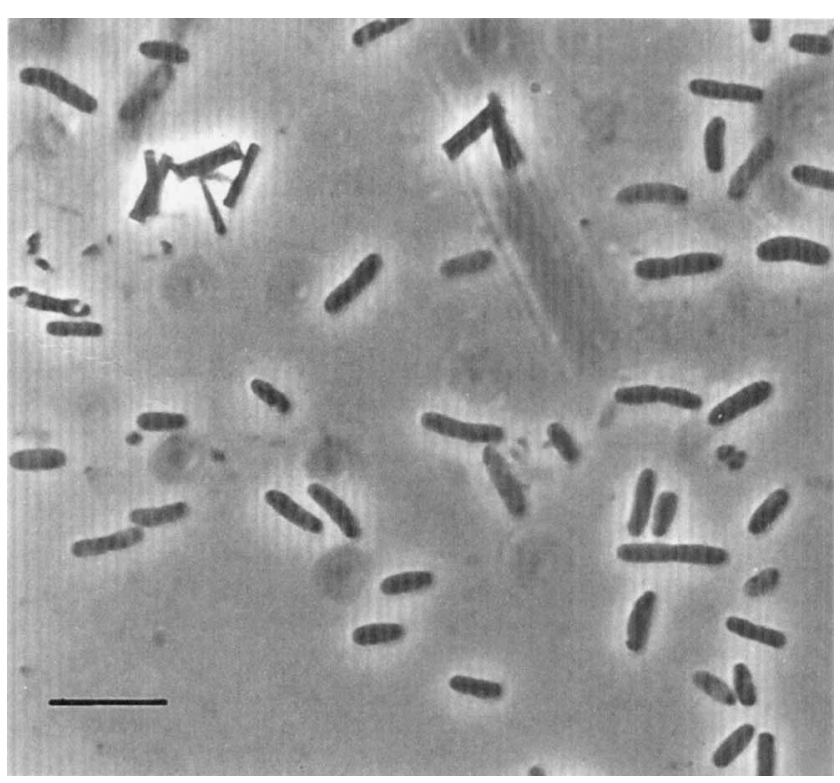

FIG. 1. Phase-contrast micrograph of strain $\mathrm{GSLS}^{\mathrm{T}}$. Bar $=5 \mu \mathrm{m}$.

$10 \mu \mathrm{l}$ of isopropanol and $5 \mu \mathrm{l}$ of $5 \mathrm{M}$ sodium acetate ( $\mathrm{pH} 5.8$ ) added were to the aqueous phase, and the preparation was mixed. The suspension was centrifuged at $13,000 \times g$, and the pellet washed with cold $80 \%$ ethanol, placed in a desiccator to evaporate the residual ethanol, suspended in $50 \mu \mathrm{l}$ of sterile distilled water, and stored at $-20^{\circ} \mathrm{C}$ until it was used.

Amplification of the 16S rRNA gene from the DNA and purification of the amplified product were performed as described previously $(14,29)$. The purified PCR product was sequenced directly with an ABI automated DNA sequencer by using a Prism dideoxy terminator cycle sequencing kit (Applied Biosystems, Ltd., Foster City, Calif.). and the protocols recommended by the manufacturer. The primers used for sequencing have been described previously (29).

The 16S rRNA sequence obtained from the sequencing data and the $16 \mathrm{~S}$ rRNA sequences of various members of the domain Bacteria obtained from the Ribosomal Database Project (version 4.0) were aligned by using sequence editor ae2 (12). Positions of sequence and alignment uncertainty were omitted from the analysis, and pairwise evolutionary distances based on 1,079 unambiguous nucleotides were computed by using the method of Jukes and Cantor (9). Dendrograms were constructed from evolutionary distances by using the neighborjoining method, a transversion analysis was performed by using the program DNAPARS, and tree topology was examined by using 100 bootstrapped data sets by running the script file dboot. For dboot we used the following sequence of events during the analysis: SEQBOOT, DNADIST, FITCH, and CONSENSE. All programs are available as part of the PHYLIP package (6). Programs available in the Molecular Evolutionary Genetic Analysis (MEGA) package, version $1(10)$, were also used in the analysis. All of the programs except MEGA were run on a Sun Sparc workstation; MEGA was run on a 386 Toshiba model T3100SX laptop computer.

Nucleotide sequence accession number. The 16S rRNA sequence of strain GSLS $^{\mathrm{T}}$ determined in this study has been deposited in the EMBL database under accession number X81850.

\section{RESULTS}

Morphology. Colonies in roll tubes and agar plates were round with entire edges, smooth, convex, opaque, and yellowish. The colony diameter was $3 \mathrm{~mm}$ after 1 week. The cells of strain GSLS ${ }^{\mathrm{T}}$ were straight rods that ranged in size from 3.3 to 5 by $0.8 \mu \mathrm{m}$ (Fig. 1) and were motile in young cultures by means of peritrichous flagella (Fig. 2). The cells occurred singly, in pairs, and rarely in chains. Strain GSLS ${ }^{T}$ was gram negative. Spores were not observed under the conditions which we tested.

Growth and physiology. Strain GSLS ${ }^{\mathrm{T}}$ was a strictly anaerobic, chemoorganotrophic bacterium. Optimal growth occurred in the presence of $10 \% \mathrm{NaCl}$. This organism was an obligate halophile and could not grow without $\mathrm{NaCl}$ in the 


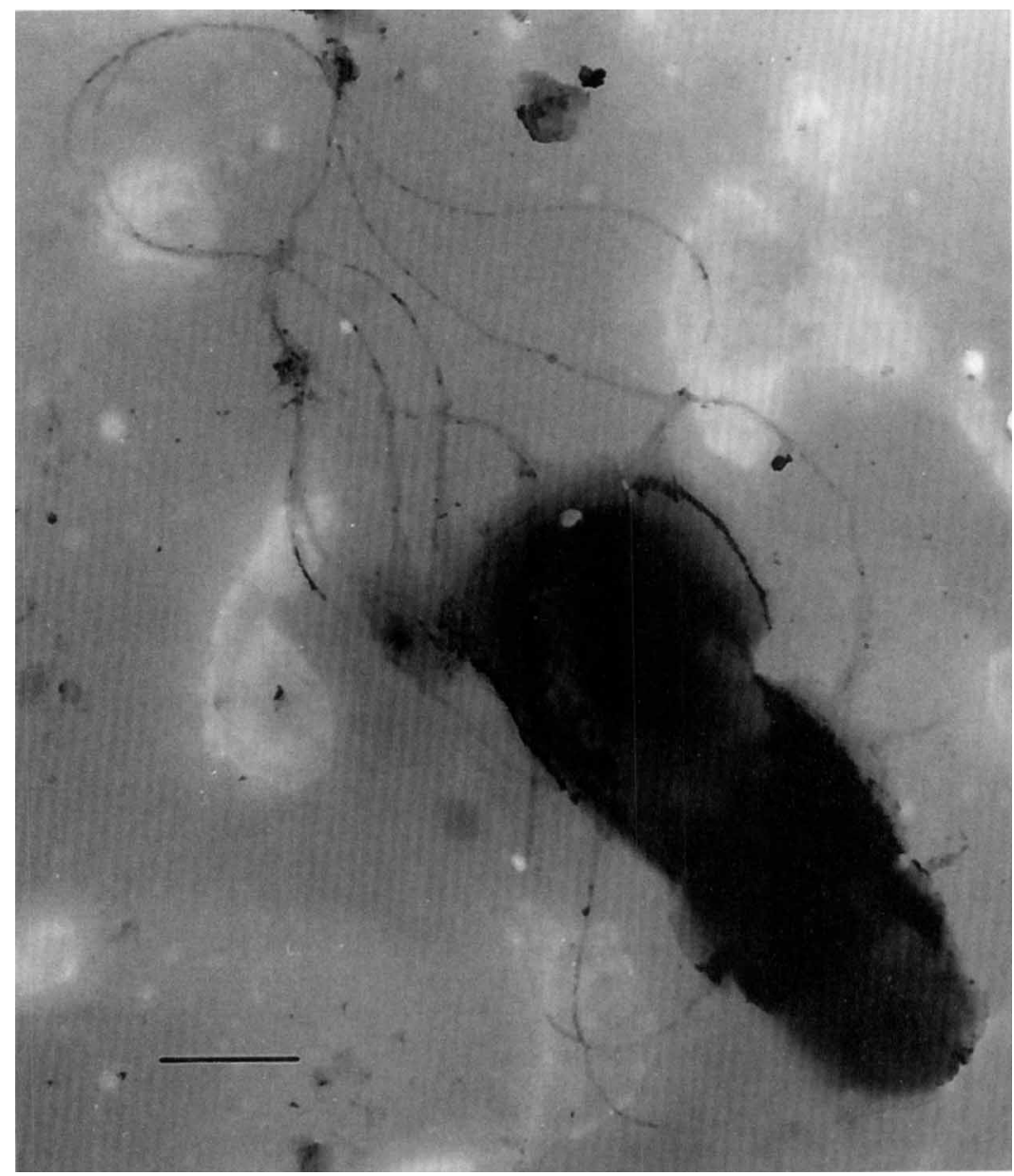

FIG. 2. Transmission electron micrograph of negatively stained strain $\mathrm{GSLS}^{\mathrm{T}}$. Bar $=0.5 \mu \mathrm{m}$.

medium. No growth occurred in the presence of $\mathrm{NaCl}$ concentrations of more than $25 \%$ (Fig. 3a). The growth rate increased when glycine buffer was added, but there was no change in the optimum $\mathrm{NaCl}$ concentration (Fig. 3a). The optimum temperature for growth was $37^{\circ} \mathrm{C}$; no growth was observed at 55 or at $15^{\circ} \mathrm{C}$ (Fig. 3b). Optimal growth occurred at $\mathrm{pH} 6.7$ to 7.0 , and the $\mathrm{pH}$ range for growth was broad ( $\mathrm{pH} 5.8$ to 10.0) (Fig. 3c). The doubling time of strain GSLS ${ }^{\mathrm{T}}$ in the presence of glucose, yeast extract, and Trypticase under optimal conditions was 3.3 $\mathrm{h}$. Growth did not occur in mineral medium when glucose was the sole carbon and energy source.

The following substrates were fermented: fructose, glucose, maltose, mannose, sucrose, $N$-acetylglucosamine, pyruvate, glycine betaine, and yeast extract. Slight growth was observed on raffinose. The following compounds were not fermented: arabinose, cellobiose, galactose, lactose, rhamnose, ribose, trehalose, xylose, glycogen, starch, adonitol, dulcitol, erythritol, glycerol, inositol, mannitol, methanol, sorbitol, formate, acetate, butyrate, propionate, citrate, lactate, oxalate, succinate, tartrate, methylamine, trimethylamine, glycine, Casamino Acids, cellulose, chitin, xylan, and pectin.

The products of glucose fermentation by strain GSLS ${ }^{\mathrm{T}}$ were acetate, lactate, butyrate, $\mathrm{CO}_{2}$, and $\mathrm{H}_{2}$. Hydrogen accounted for 0.26 and $0.09 \mathrm{mmol}$ of the metabolites obtained from fermentation of $0.32 \mathrm{mmol}$ of glucose and $0.52 \mathrm{mmol}$ of pyruvate, respectively. Fumarate, nitrate, and sulfate were not used as electron acceptors. No growth was observed on $\mathrm{H}_{2}-\mathrm{CO}_{2}$.

Degradation of glycine betaine by the coculture of strain GSLS $^{\mathrm{T}}$ and $M$. mahii produced acetate and methane (Fig. 4). The amount of methane produced from $1.7 \mathrm{mmol}$ of glycine betaine was $0.86 \mathrm{mmol}$.

Strain GSLS ${ }^{\mathrm{T}}$ exhibited strong antibiotic resistance; growth was inhibited by $200 \mu \mathrm{g}$ of penicillin $\mathrm{G}$ per $\mathrm{ml}, 400 \mu \mathrm{g}$ of D-cycloserine per ml, $400 \mu \mathrm{g}$ of tetracycline per $\mathrm{ml}$, and 1,000 $\mu \mathrm{g}$ of streptomycin per ml.

DNA base composition. The $\mathrm{G}+\mathrm{C}$ content of strain $\mathrm{GSLS}^{\mathrm{T}}$ DNA as determined in triplicate by HPLC was $31 \mathrm{~mol} \%$.

$16 S$ rRNA sequence analysis. Ưsing eight primers, we determined nearly the complete sequence of the 16S rRNA gene of isolate GSLS ${ }^{\mathrm{T}}$. This sequence (positions 8 to 1443; Escherichia coli numbering of Winker and Woese [35]) was aligned with other sequences, and a phylogenetic analysis was performed with representatives of the various phyla of the domain Bacteria. This analysis revealed that isolate GSLS ${ }^{\mathrm{T}}$ was a member of the low-G+C-content gram-positive phylum. Additional sequence alignments and phylogenetic analysis performed with members of this phylum revealed that the closest relatives of isolate GSLS ${ }^{\mathrm{T}}$ were Haloanaerobium species and that Haloanaerobium praevalens was more closely related (level of similarity, $98.1 \%$ ) than Haloanaerobium salsugo (level of sim- 

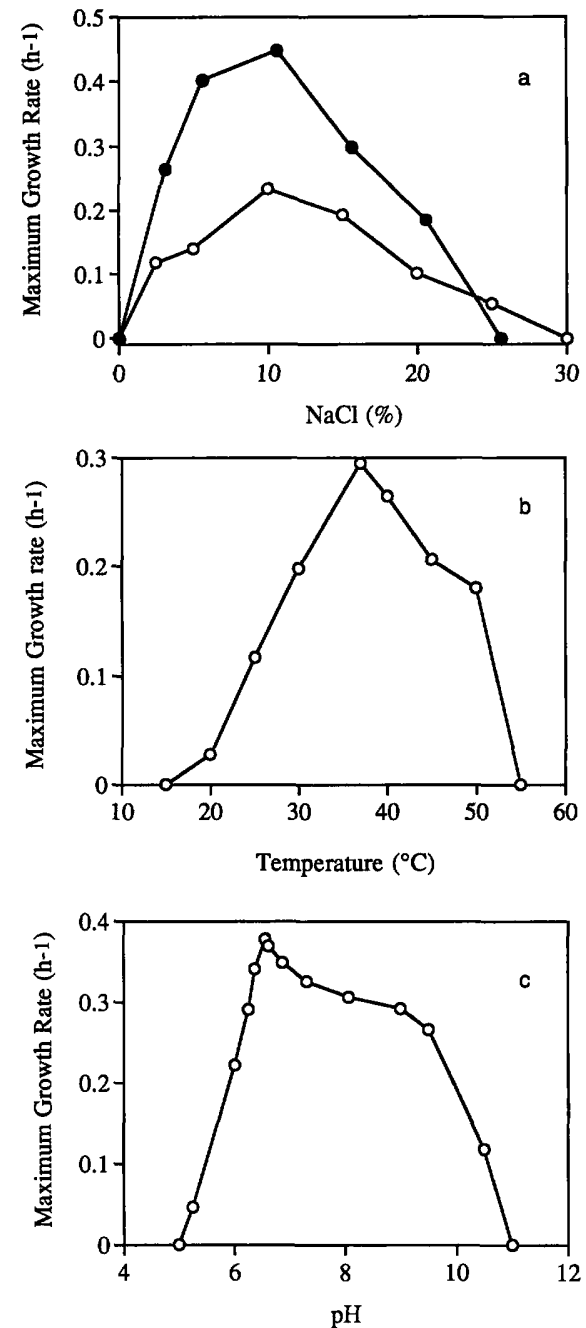

FIG. 3. (a) Effect of $\mathrm{NaCl}$ concentration on the growth of strain GSLS Symbols: $O$, carbonate buffer; 9 , glycine buffer. (b) Effect of temperature on the growth of strain GSLS ${ }^{\mathrm{T}}$. (c) Effect of $\mathrm{pH}$ on the growth of strain GSLS ${ }^{\mathrm{T}}$.

ilarity, 94.4\%) (Table 1). Figure 5 is a dendrogram generated by the neighbor-joining method (6) from a Jukes-Cantor evolutionary similarity matrix (9) (Table 1) and shows this relationship. A parsimony analysis produced the same tree topology, and a bootstrap analysis revealed that strain GSLS ${ }^{\mathrm{T}}$ was not closely related to Haloanaerobium praevalens (level of similarity, $75 \%$ ).

\section{DISCUSSION}

Only a limited variety of forms of life inhabit hypersaline ecosystems, although a wide range of substrates are available. Invertebrates, algae, and prokaryotes are the major sources of organic matter in these environments. Brine shrimps or brine flies produce proteins and chitin. At high salt concentrations, cyanobacteria and members of the Halobacteriaceae provide significant quantities of organic matter from decomposition of their cell walls, which are composed of sugars, proteins, and lipids. Organic osmolytes which maintain cell turgor pressure in the presence of high salt concentrations also contribute to the overall carbon cycle in hypersaline ecosystems. Aerobic

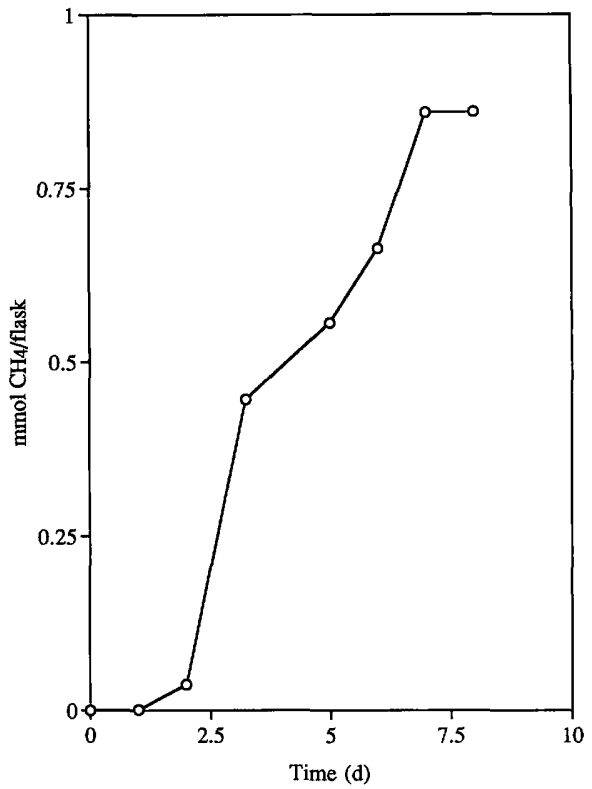

FIG. 4. Methane evolution during growth of a coculture of strain GSLS ${ }^{\mathbf{T}}$ and M. mahii on glycine betaine.

halophilic (eu)bacteria accumulate low-molecular-weight organic compounds (such as glycine betaine) in addition to potassium as an adaptation to osmotic stress (19).

The main characteristic of strain GSLS ${ }^{\mathrm{T}}$ which distinguishes this organism from the other fermentative halophiles is the use of glycine betaine, an osmolyte found in all halophilic (eu)bacteria. This compound could be the main carbon source for strain GSLS ${ }^{\mathrm{T}}$ in its natural environment. The metabolic pathway of glycine betaine degradation leads to the formation of acetate and trimethylamine, two substrates for methanogens, according the following equations: $\left(\mathrm{CH}_{3}\right)_{3} \mathrm{NCH}_{2} \mathrm{COOH}+0.5$ $\mathrm{H}_{2} \rightarrow \mathrm{CH}_{3} \mathrm{COOH}+\mathrm{N}\left(\mathrm{CH}_{3}\right)_{3}$ and $4\left(\mathrm{CH}_{3}\right)_{3} \mathrm{NH}^{+}+9 \mathrm{H}_{2} \mathrm{O} \rightarrow$ $9 \mathrm{CH}_{4}+3 \mathrm{HCO}_{3}^{-}+4 \mathrm{NH}_{4}^{+}+3 \mathrm{H}^{+}$.

Only methylotrophic halophilic methanogens have been described previously; these organisms include $M$. mahii, which has also been isolated from Great Salt Lake $(24,25)$. When strain GSLS ${ }^{\mathbf{T}}$ was grown in a coculture with $M$. mahii in the presence of glycine betaine, acetate and methane accumulated. The methane originated from the use of trimethylamine, a metabolite of glycine betaine degradation by strain GSLS ${ }^{\mathrm{T}}$, by the methylotrophic methanogen.

Growth of strain GSLS $^{\mathrm{T}}$ was enhanced by using glycine buffer, but the reason for this is unclear; it may be that transport of glycine betaine is improved in the presence of glycine, which is analogous to the situation found with proline (26), or that glycine itself is used as an additional carbon source, which improves the yield and growth rate.

Its fermentation pathway clearly distinguishes strain GSLS ${ }^{\mathrm{T}}$ from the other halophilic anaerobic bacteria that have been described (Table 2). Strain GSLS ${ }^{\mathrm{T}}$ produces acetate, butyrate, lactate, and $\mathrm{H}_{2}$, and $\mathrm{CO}_{2}$ from glucose according the following equation: 1 glucose $\rightarrow 0.5$ acetate +0.7 butyrate +0.5 lactate $+3 \mathrm{H}_{2}+x \mathrm{CO}_{2}$.

Several recent microbial ecological investigations of Great Salt Lake have revealed that both aerobic microflora (7) and anaerobic microflora (27) are present. New species of fermentative (36) and methanogenic $(24,25)$ bacteria have also been isolated from this environment. Strain GSLS ${ }^{\mathrm{T}}$ is another or- 
TABLE 1. Dissimilarity matrix derived from a comparison of the 16S rRNA sequences of Haloanaerobium alcaliphilum and other gram-positive bacteria ${ }^{a}$

\begin{tabular}{|c|c|c|c|c|c|c|c|c|c|c|c|c|c|c|}
\hline \multirow[b]{2}{*}{ Species } & \multicolumn{14}{|c|}{$\%$ Sequence dissimilarity } \\
\hline & 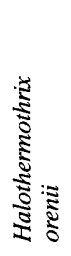 & 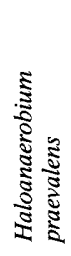 & 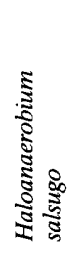 & 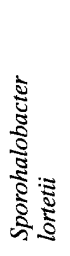 & 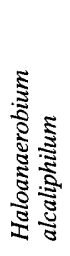 & 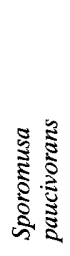 & 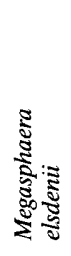 & 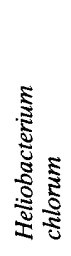 & 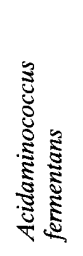 & 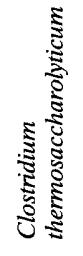 & 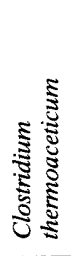 & 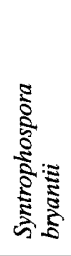 & 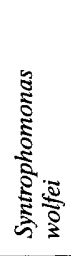 & 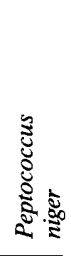 \\
\hline Haloanaerobium praevalens & 15.2 & & & & & & & & & & & & & \\
\hline Haloanaerobium salsugo & 13.6 & 4.3 & & & & & & & & & & & & \\
\hline Sporohalobacter lortetii & 16.4 & 18.8 & 18.9 & & & & & & & & & & & \\
\hline Haloanaerobium alcaliphilum & 16.7 & 1.9 & 5.6 & 20.0 & & & & & & & & & & \\
\hline Sporomusa paucivorans & 22.5 & 24.3 & 23.8 & 23.5 & 26.0 & & & & & & & & & \\
\hline Megasphaera elsdenii & 22.2 & 24.1 & 24.2 & 23.1 & 26.1 & 16.4 & & & & & & & & \\
\hline Heliobacterium chlorum & 21.0 & 25.6 & 23.6 & 23.6 & 27.1 & 19.0 & 20.9 & & & & & & & \\
\hline Acidaminococcus fermentans & 21.5 & 24.6 & 23.9 & 23.1 & 26.6 & 13.5 & 16.2 & 20.8 & & & & & & \\
\hline Clostridium thermosaccharolyticum & 20.1 & 23.1 & 21.5 & 21.3 & 24.3 & 22.6 & 20.1 & 18.7 & 21.5 & & & & & \\
\hline Clostridium thermoaceticum & 19.0 & 20.8 & 21.4 & 19.0 & 22.5 & 19.0 & 18.4 & 17.8 & 20.3 & 14.0 & & & & \\
\hline Syntrophospora bryantii & 20.0 & 24.3 & 23.9 & 21.0 & 26.1 & 20.9 & 21.4 & 17.5 & 21.8 & 17.9 & 15.2 & & & \\
\hline Syntrophomonas wolfei & 20.9 & 23.1 & 23.0 & 23.0 & 24.8 & 21.4 & 20.8 & 18.1 & 21.3 & 18.0 & 14.4 & 6.1 & & \\
\hline Peptococcus niger & 22.0 & 23.5 & 24.1 & 23.0 & 25.0 & 22.4 & 20.1 & 19.0 & 21.3 & 20.3 & 16.6 & 18.6 & 17.9 & \\
\hline Propionigenium modestum & 28.8 & 29.6 & 29.0 & 27.4 & 31.1 & 27.1 & 25.1 & 25.5 & 27.3 & 25.5 & 25.0 & 26.6 & 26.4 & 27.5 \\
\hline
\end{tabular}

${ }^{a}$ The sequences used in the analysis were obtained from the Ribosomal Database Project, version 4.0 (12). Only 1,079 unambiguous nucleotide positions were used in the analysis.

ganism found in this habitat. Strain GSLS ${ }^{\mathrm{T}}$ differs markedly from all previously described isolates by its formation of large amount of hydrogen during glucose fermentation. According to Phelps and Zeikus (27), $\mathrm{H}_{2}$ accumulates in sediments of Great Salt Lake. Perhaps strain GSLS ${ }^{\mathrm{T}}$ plays a role in hydrogen production in these sediments.

Morphological and physiological characteristics further distinguish strain GSLS ${ }^{\mathrm{T}}$ from other fermentative halophiles (Table 2). $A$. arabaticum and strain GSLS ${ }^{\mathbf{T}}$ are the only alkalinetolerant isolates that have been described so far, and only strain GSLS ${ }^{\mathrm{T}}$ grows at $\mathrm{pH}$ values greater than 8.5 . Within the genus Haloanaerobium, strain GSLS ${ }^{\mathrm{T}}$ is the only motile isolate.

Phylogenetically, strain GSLS ${ }^{\mathrm{T}}$ is related to Haloanaerobium praevalens (level of similarity, 98.1\%) and Haloanaerobium sal-

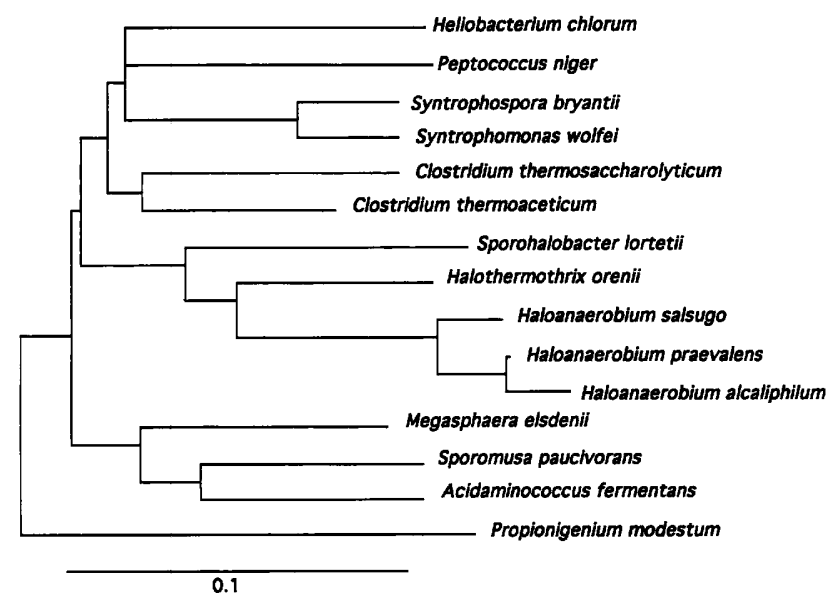

FIG. 5. Dendrogram showing the position of Haloanaerobium alcaliphilum GSLS $^{\mathrm{T}}$ among representative members of the genus Haloanaerobium and related genera. The dendrogram was derived from the dissimilarity matrix shown in Table 1. sugo (level of similarity, 94.4\%), but is different enough to warrant designation of a new Haloanaerobium species. Strain GSLS $^{\mathrm{T}}$ also differs markedly in its $\mathrm{G}+\mathrm{C}$ content $(31 \mathrm{~mol} \%)$ from Haloanaerobium praevalens $(27 \mathrm{~mol} \%)$ and Haloanaerobium salsugo ( $34 \mathrm{~mol} \%$ ); thus, the $\mathrm{G}+\mathrm{C}$ content data support the proposal that strain GSLS ${ }^{\mathrm{T}}$ belongs to a new Haloanaerobium species.

We propose that strain GSLS is the type strain of a new species of the genus Haloanaerobium, Haloanaerobium alcaliphilum.

Description of Haloanaerobium alcaliphilum. Haloanaerobium alcaliphilum (al.ca.li' phi.lum. N. L. n. alcali, from Arabic al, end, and qaliy, soda ash; Gr. adj. philum, loving; N. L. adj. alcaliphilum, liking alkaline media). Cells are straight rods that are 3.3 to 5 by $0.8 \mu \mathrm{m}$, are motile by means of peritrichous flagella, and occur singly, in pairs, or rarely in chains. Gram negative. Spores are not formed. Colonies (diameter, up to 3 $\mathrm{mm}$ ) are round with entire edges, smooth, convex, opaque, and yellowish. Moderately halophilic. Optimum $\mathrm{NaCl}$ concentration for growth, $10 \%$; range of $\mathrm{NaCl}$ concentrations for growth, 2.5 to $25 \%$. Optimum temperature for growth, $37^{\circ} \mathrm{C}$; growth occurs at 25 to $50^{\circ} \mathrm{C}$. Alkalitolerant. $\mathrm{pH}$ range, 5.8 to 10.0 ; optimum $\mathrm{pH}, 6.7$ to 7.0 . Growth factors found in yeast extract are required for growth. Cells are resistant to penicillin $\mathrm{G}(200$ $\mu \mathrm{g} / \mathrm{ml})$, D-cycloserine $(400 \mu \mathrm{g} / \mathrm{ml})$, tetracycline $(400 \mu \mathrm{g} / \mathrm{ml})$, and streptomycin $(1,000 \mu \mathrm{g} / \mathrm{ml})$.

Strictly anaerobic. Chemoorganotrophic. Fumarate, nitrate, and sulfate are not reduced. No growth occurs with $\mathrm{H}_{2}-\mathrm{CO}_{2}$.

Ferments fructose, glucose, maltose, mannose, sucrose, $N$ acetylglucosamine, pyruvate, glycine betaine, and yeast extract. End products of glucose fermentation are acetate, butyrate, lactate, $\mathrm{H}_{2}$, and $\mathrm{CO}_{2}$. Acetate and trimethylamine are produced from glycine betaine.

The $\mathrm{G}+\mathrm{C}$ content is $31 \mathrm{~mol} \%$ (as determined by HPLC).

Type strain GSLS (= DSM 8275) was isolated from the north arm of Great Salt Lake in Utah. 


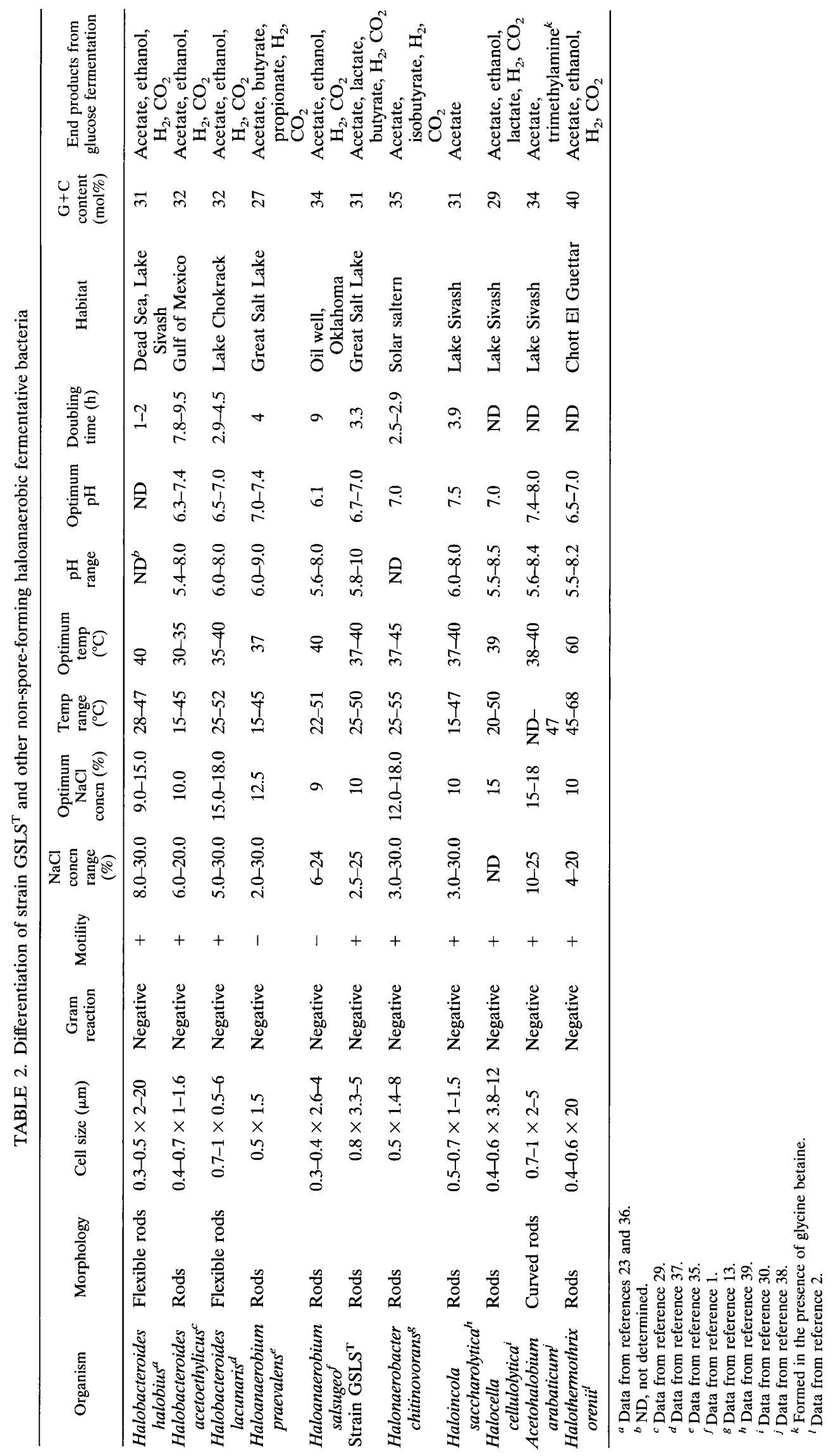




\section{ACKNOWLEDGMENTS}

We are indebted to D. R. Boone for providing the M. mahii strain, Chi-Yu Huang for technical assistance, and K. D. Jahnke for determining the DNA base ratio.

\section{REFERENCES}

1. Bhupathiraju, V. K., A. Oren, P. K. Sharma, R. S. Tanner, C. R. Woese, and M. J. McInerney. 1994. Haloanaerobium salsugo sp. nov., a moderately halophilic, anaerobic bacterium from a subterranean brine. Int. J. Syst. Bacteriol. 44:565-572.

2. Cayol, J.-L., B. Ollivier, A. Lawson Anani Soh, M.-L. Fardeau, E. Ageron, P. A. D. Grimont, G. Prensier, J. Guezennec, M. Magot, and J.-L. Garcia. 1994. Haloincola saccharolytica subsp. senegalensis subsp. nov., isolated from the sediments of a hypersaline lake, and emended description of Haloincola saccharolytica. Int. J. Syst. Bacteriol. 44:805-811.

3. Cayol, J.-L., B. Ollivier, B. K. C. Patel, G. Prensier, J. Guezennec, and J.-L. Garcia. 1994. Isolation and characterization of Halothermothrix orenii gen. nov., sp. nov., a halophilic, thermophilic, fermentative, strictly anaerobic bacterium. Int. J. Syst. Bacteriol. 44:534-540.

4. Cord-Ruwisch, R. 1985. A quick method for the determination of dissolved and precipitated sulfides in cultures of sulfate-reducing bacteria. J. Microbiol. Methods 4:33-36.

5. Cord-Ruwisch, R., B. Ollivier, and J.-L. Garcia. 1986. Fructose degradation by Desulfovibrio sp. in pure culture and in coculture with Methanospirillum hungatei. Curr. Microbiol. 13:285-289.

6. Felsenstein, J. 1993. PHYLIP (phylogenetic interference package), version 3.51c. Department of Genetics, University of Washington, Seattle.

7. Fendrich, C., and B. Schink. 1988. Degradation of glucose, glycerol and acetate by aerobic bacteria in surface water of Great Salt Lake, Utah, USA. Syst. Appl. Microbiol. 11:94-96.

8. Hungate, R. E. 1969. A roll tube method for the cultivation of strict anaerobes. Methods Microbiol. 3B:117-132.

9. Jukes, T. H., and C. R. Cantor. 1969. Evolution of protein molecules, p. 21-132. In H. N. Munro (ed.), Mammalian protein metabolism. Academic Press, Inc., New York.

10. Kumar, S., K. Tamura, and M. Nei. 1993. MEGA: molecular evolutionary genetic analysis, version 1.0. The Pennsylvania State University, University Park.

11. Larsen, H. 1962. Halophilism, p. 297-342. In I. C. Gunsalus and R. Y. Stanier (ed.), The bacteria, vol. 4. Academic Press, Inc., New York.

12. Larsen, N., G. J. Olsen, B. L. Maidak, M. J. McCaughey, R. Overbeek, T. J. Macke, T. L. Marsh, and C. R. Woese. 1993. The Ribosomal Database Project. Nucleic Acids Res. 21(Suppl.):3021-3023.

13. Liaw, H. J., and R. A. Mah. 1992. Isolation and characterization of Haloanaerobacter chitinovorans gen. nov., sp. nov., a halophilic, anaerobic, chitinolytic bacterium from a solar saltern. Appl. Environ. Microbiol. 58: 260-266.

14. Love, C. A., B. K. C. Patel, P. D. Nichols, and E. Stackebrandt. 1993. Desulfotomaculum australicum $\mathrm{sp}$. nov., a thermophilic sulfate-reducing bacterium isolated from the Great Artesian Basin of Australia. Syst. Appl. Microbiol. 16:244-251.

15. Macy, J. M., J. E. Snellen, and R. E. Hungate. 1972. Use of syringe methods for anaerobiosis. Am. J. Clin. Nutr. 25:1318-1323.

16. Meshbah, M., U. Premachandran, and W. B. Whitman. 1989. Precise measurement of the $\mathrm{G}+\mathrm{C}$ content of deoxyribonucleic acid by high-performance liquid chromatography. Int. J. Syst. Bacteriol. 39:159-167.

17. Miller, T. L., and M. J. Wolin. 1974. A serum bottle modification of the Hungate technique for cultivating obligate anaerobes. Appl. Microbiol. 27: 985-987.

18. Ollivier, B., P. Caumette, J.-L. Garcia, and R. A. Mah. 1993. Anaerobic bacteria from hypersaline environments. Microbiol. Rev. 58:27-38.

19. Oren, A. 1990 . Formation and breakdown of glycine betaine and trimethylamine in hypersaline environments. Antonie Leeuwenhoek 58:291-298.

20. Oren, A. 1992. The genera Haloanaerobium, Halobacteroides, and Sporoha- lobacter, p. 1893-1900. In A. Balows, H. G. Trüper, M. Dworkin, W. Harder, and K. H. Schleifer (ed.), The prokaryotes, 2nd ed., vol. 2. Springer-Verlag, New York.

21. Oren, A., B. J. Paster, and C. R. Woese. 1984. Haloanaerobiaceae: a new family of moderately halophilic obligatory anaerobic bacteria. Syst. Appl. Microbiol. 5:71-80.

22. Oren, A., H. Pohla, and E. Stackebrandt. 1987. Transfer of Clostridium lortetii to new genus Sporohalobacter gen. nov. as Sporohalobacter lortetii comb. nov., and description of Sporohalobacter marismortui sp. nov. Syst. Appl. Microbiol. 9:239-246.

23. Oren, A., W. G. Weisburg, M. Kessel, and C. R. Woese. 1984. Halobacteroides halobius gen. nov., sp. nov., a moderately halophilic anaerobic bacterium from the bottom sediments of the Dead Sea. Syst. Appl. Microbiol. 5:58-70.

24. Paterek, J. R., and P. H. Smith. 1985. Isolation and characterization of a halophilic methanogen from Great Salt Lake. Appl. Environ. Microbiol. 50:877-881.

25. Paterek, J. R., and P. H. Smith. 1988. Methanohalophilus mahii gen. nov., sp. nov., a methylotrophic halophilic methanogen. Int. J. Syst. Bacteriol. 38:122123.

26. Perroud, B., and D. Le Rudelier. 1985. Glycine betaine transport in Escherichia coli: osmotic modulation. J. Bacteriol. 161:393-401.

27. Phelps, T., and J. G. Zeikus. 1980. Microbial ecology of anaerobic decomposition in Great Salt Lake, abstr. 14, p. 89. In Abstracts of the 80th General Meeting of the American Society for Microbiology 1980. American Society for Microbiology, Washington, D.C.

28. Pitcher, D. G., N. A. Saunders, and R. J. Owen. 1989. Rapid extraction of bacterial genomic DNA with guanidium thiocyanate. Lett. Appl. Microbiol. 8:151-156.

29. Redburn, A. C., and B. K. C. Patel. 1993. Phylogenetic analysis of Desulfotomaculum thermobenzoicum using polymerase chain reaction-amplified $16 \mathrm{~S}$ rRNA-specific DNA. FEMS Microbiol. Lett. 113:81-86.

30. Rengpipat, S., T. A. Langworthy, and J. G. Zeikus. 1988. Halobacteroides acetoethylicus sp. nov., a new obligately anaerobic halophile isolated from deep surface hypersaline environments. Syst. Appl. Microbiol. 11:28-35.

31. Simankova, M. V., N. A. Chernych, G. A. Osipov, and G. A. Zavarzin. 1992. Halocella cellulolytica gen. nov., spec. nov., a new obligately anaerobic, halophilic, cellulolytic bacterium. Syst. Appl. Microbiol. 16:385-389.

32. Sober, H. A. 1968. Handbook of biochemistry. The Chemical Rubber Co., Cleveland.

33. Tamaoka, J., and K. Komagata. 1984. Determination of DNA base composition by reverse-phase high-performance liquid chromatography. FEMS Microbiol. Lett. 25:125-128.

34. Vreeland, R. H., and L. I. Hochstein. 1993. The biology of halophilic bacteria. CRC Press, Boca Raton, Fla.

35. Winker, S., and C. R. Woese. 1991. A definition of the domains Archaea, Bacteria and Eucarya in terms of small subunit ribosomal RNA characteristics. Syst. Appl. Microbiol. 13:161-165.

36. Zeikus, J. G., P. W. Hegge, T. E. Thompson, T. J. Phelps, and T. A. Langworthy. 1983. Isolation and description of Haloanaerobium praevalens gen. nov. and sp. nov., an obligately anaerobic halophile common to Great Salt Lake sediments. Curr. Microbiol. 9:225-234.

37. Zhilina, T. N., V. V. Kevbrin, A. M. Lysenko, and G. A. Zavarzin. 1991. Isolation of saccharolytic anaerobes from a halophilic cyanobacterial mat. Microbiology (Engl. Transl. Mikrobiologiya) 60:101-107.

38. Zhilina, T. N., L. V. Miroshnikova, G. A. Osipov, and G. A. Zavarzin. 1991. Halobacteroides lacunaris sp. nov., new saccharolytic, anaerobic, extremely halophilic organism from the lagoon-like hypersaline Lake Chokrak. Microbiology (Engl. Transl. Mikrobiologiya) 60:495-503.

39. Zhilina, T. N., and G. A. Zavarzin. 1990. A new extremely halophile homoacetogen bacterium, Acetohalobium arabaticum gen. nov., sp. nov. Dokl. Akad. Nauk SSSR 311:745-747. (In Russian.)

40. Zhilina, T. N., G. A. Zavarzin, E. S. Bulygina, V. V. Kevbrin, G. A. Osipov, and K. M. Chumakov. 1992. Ecology, physiology and taxonomy studies on a new taxon of Haloanaerobiaceae, Haloincola saccharolytica gen. nov., sp. nov. Syst. Appl. Microbiol. 15:275-284. 